Article

\title{
Green Production as a Factor of Survival for Innovative Startups: Evidence from Italy
}

\author{
Riccardo Gianluigi Serio ${ }^{1, *}$, Maria Michela Dickson ${ }^{2}\left(\mathbb{D}\right.$, Diego Giuliani ${ }^{2}{ }^{(1)}$ and Giuseppe Espa ${ }^{2}$ \\ 1 Faculty of Law, University of Trento, 38122 Trento, Italy \\ 2 Department of Economics and Management, University of Trento, 38122 Trento, Italy; \\ mariamichela.dickson@unitn.it (M.M.D.); diego.giuliani@unitn.it (D.G.); giuseppe.espa@unitn.it (G.E.) \\ * Correspondence: riccardo.serio@unitn.it
}

Received: 8 October 2020; Accepted: 11 November 2020; Published: 13 November 2020

\begin{abstract}
Many studies have analyzed empirically the determinants of survival for innovative startup companies using data about the characteristics of entrepreneurs and management or focusing on firm- and industry-specific variables. However, no attempts have been made so far to assess the role of the environmental sustainability of the production process. Based on data describing the characteristics of the Italian innovative startups in the period 2009-2018, this article studies the differences in survival between green and non-green companies. We show that, while controlling for other confounding factors, startups characterized by a green production process tend to survive longer than their counterparts. In particular, we estimate that a green innovative startup is more than twice as likely to survive than a non-green one. This evidence may support the idea that environmental sustainability can help economic development.
\end{abstract}

Keywords: newborn companies; Kaplan-Meier; Cox proportional-hazard model

\section{Introduction}

Innovation has always been a distinguishing activity of humanity. From the wheel to the invention of the world wide web, it constitutes an indissoluble common thread, inherent in human nature itself. Innovation is also crucial for economic growth and sustainability. Following the growing pressure brought about by international competition, it is now a duty for companies and modern nations to innovate. An important component of the engine of innovation is to be found in startup companies. The term startup appears for the first time on Forbes in 1976 [1] to indicate a new type of company and not an embryonic phase of the life of incumbent companies. Since then, the attention on the topic has been growing due to the occurrence of positive association among new business initiatives, innovation rate and economic growth [2-5].

Startups may stimulate economies by promoting innovation [6-9]. The most innovative ones often report better performances $[10,11]$, contribute positively to the creation of new jobs and to the development of new sectors [12-14], and, more in general, fuel an overall improvement of the welfare system [15-19].

Despite their contribution to innovation and economic development, startups often struggle to survive for a long time in the market, because of the higher difficulties they face, especially at the beginning of their business activity. The greatest problem that newborn companies deal with concern the so-called liability of newness [20,21], which is usually associated with the scarcity of resources that new entries need to have access to start and develop the business. Indeed, some balance sheet indicators, such as a consistent liquidity, very low leverage ratio and the ability to make profits, have been shown to be important predictors of success or failure of a startup, especially in the preliminary stages of its life [22]. Other features that may affect the positive result of a newborn business activity 
concern the characteristics of the entrepreneur, e.g., his/her previous work experiences in the business world [23-25] or his/her ability to cooperate [26,27]. As a result, newborn companies, and hence startups, may experience high failure rates [28,29], especially those that reproduce existing products [30].

Recently, many innovation activities have been dedicated to the problem of using and searching for alternative energy sources to mitigate the impact of human activities on Earth, according to the so-called green economy. Indeed, pursuing a sustainable development is more and more a global issue [31-33]. When the will to innovate meets the need to pursue sustainability, innovative startups play a crucial role [34]. Given that, it is reasonable to expect some form of attention and protection by the policy maker aimed at promoting the development of new business initiatives focused on sustainable technological innovation. Some studies have reported evidence that seems to validate this assumption [35]. The goal of policy makers is to intensify technology transfer and market competition to speed up the evolution of the industrial network and hence to increase production and employment [36-38]. In particular, it has been shown that sustainability-oriented technologies offer the opportunity to restore competitiveness in saturated, mature western economies [39-41]. Indeed, in recent years, the green economy has been one of the best responses to the economic crisis. Not surprisingly, startups have also been interested in green consciousness, given the possibility to receive additional benefits if adopting environmental ethics.

However, while it is true that companies devoted to a sustainable production have recently gained an increase in growth, this does not necessarily go along with a higher probability of surviving in the market, which should be a central topic for startups. Although several contributions in the literature addressed the issue of identifying the factors of survival [42] and development of young innovative companies [43], few studies have focused on investigating the link between sustainable development and neo-entrepreneurial activity [44].

This paper aims at filling this gap in the literature by assessing whether and how the risk of market exits that innovative startups face is affected by the environmental sustainability of their production process. In particular, exploiting data about the population of Italian innovative startups in the period 2009-2018 and by means of the Cox proportional-hazard model, we verify that green startups have a relatively higher survival performance compared to the non-green ones, while controlling for other structural factors that influence firm survival.

The paper is structured as follows. Section 2 briefly describes the current Italian legislative framework of innovative startups, that is the Italian Startup Act. In Section 3, the statistical framework is presented. In Section 4, the dataset about Italian innovative startups on which the analyses are conducted is presented, and interesting insights are brought to light. In Section 5 is offered a discussion of the results. Section 6 concludes the paper.

\section{The Italian Legislative Framework of Innovative Startups: the "Startup Act"}

At the end of 2012, the Italian government decided to intervene to improve the context for the birth and growth of newborn companies through the so-called Italian Startup Act (Law no. 221/2012), which introduces the definition of a new innovative company in the Italian legal system, namely the innovative startup (hereinafter ISU). Requirements to be considered ISU are related to the nationality (being registered in Italy or in another EU country but with a production branch in Italy), age (aged less than 5 years) and core business (which must be centered on research, development, production, marketing of innovative products with high technological value) of the company. In addition, an ISU must satisfy at least two of three additional requirements, such as: expenses in R\&D and innovation must be at least $15 \%$ of either its annual costs or its turnover; employment of highly qualified personnel, such as at least one third of employees being PhD holders and students, or researchers, or at least two thirds being M.Sc. graduates; the company must be the owner, depositary or licensee of a registered patent, or the owner of a registered software [45]. Newborn companies respecting these requirements may be registered in the special section for innovative startups of the Italian Business Register. The aim of the Italian legislator was clearly the creation of an environment for the development of new 
entrepreneurial ideas with a highly innovative character. Therefore, the possibility to be defined as ISUs was contemplated also for companies that comply with the requirements for a period (i) not exceeding four years, if the company was born up to 2 years before starting the activity, (ii) not exceeding three years, if established between 2009 and 2010, and (iii) up to two years, if registered in the Italian Business Register between 2008 and 2009. Companies falling into the definition of ISUs may enjoy a substantial number of preferential treatments, going from the purely bureaucratic sphere to tax, financing and governance grants. Examples of the first are the cut of many red tape rules and exemption from paying annual fees and duty stamps, while examples of the second are tax incentives for equity investors, an easier compensation of Value Added Tax credits, the extension of terms to cover systematic losses, flexible corporate management, tailor-made labor laws, remuneration of employees and consultants through stock options and work for equity (not included in taxable income), non-compulsory operationality tests to verify the inactivity status, facilitation and speeding up of bankruptcy procedures, and many others $[21,36]$. The Italian regulation on ISUs provides a particular kind of innovative startup defined as "high technological value companies in energy related fields". These companies are intended as green startups (in contrast with non-green startups), which shall establish green oriented activities, regardless of their specific sector of activity. Business literature and empirical evidence show that nowadays sustainability and innovation go hand in hand and feed into themselves. Adopting a green approach means, for newborn companies, to transform initial difficulties into opportunities. Although Italy has been lagging in the green transition, the last GreenItaly report [46] has pointed out that $31.2 \%$ of the entire non-agricultural entrepreneurship has invested in the period 2015-2018, or plan to invest by the end of 2019, in green products and technologies in order to reduce environmental impacts, save energy and curb $\mathrm{CO}_{2}$ emissions. Therefore, we argue that the innovative startups belonging to this class can be properly considered as green as opposed to the non-green ones. This categorization can then help in assessing whether greenness positively affects the survival performance of innovative startups.

\section{Empirical Methodology: Survival Analysis}

The proper empirical methodology to assess the determinants of survival time of a company, that is the time occurring between the entry of a company into the market and its exit from the market, is the so-called survival (or duration) analysis. Unlike the more traditional regression modelling approaches, such as the logistic regression, survival analysis can specifically deal with the inevitable occurrence of censoring, that is the presence of truncated observations due to the fact that the actual survival time of a company can be longer than its observed follow-up time. In particular, in order to study the relationship between company survival performance and greenness in production, we employ Kaplan-Meier curves and the Cox proportional-hazards regression model.

\subsection{Descriptive Survival Analysis: The Kaplan-Meier Curves}

Following the approach by Kaplan and Meier [47], it is possible to estimate the company survival probability non-parametrically using the observed survival times, both censored and uncensored, of each company.

Consider that $k$ companies cease to operate during the time interval under observation at distinct points in time $t_{1}<t_{2}<t_{3}<\ldots<t_{k}$. Assuming that exits of companies from the market occur independently of one another, the probabilities of surviving from one point in time to the successive one can be multiplied together to give the cumulative survival probability. In other words, the probability that a company is still on the market at $t_{j}$, say $S\left(t_{j}\right)$, can be calculated from $S\left(t_{j-1}\right)$ as follows:

$$
S\left(t_{j}\right)=S\left(t_{j-1}\right)\left(1-\frac{d_{j}}{n_{j}}\right)
$$


where $n_{j}$ is the number of companies still being on the market just before $t_{j}$ and $d_{j}$ represents the number of companies that exit from market at $t_{j}$. Obviously, since $t_{0}=0$, then $S(0)=1$. The value of $S(t)$ is necessarily constant between successive points in time, thus implying that the estimated probability is a step function that varies only at the point in time of each exit. The Kaplan-Meier (hereinafter $\mathrm{KM}$ ) survival curve is the plot of $S(t)$ against $t$ and may provide a useful summary of the survival performance of companies.

In addition, the comparison between the KM curves of different subgroups of companies, such as the groups of green and non-green startups, makes it possible to identify the presence of factors affecting survival. Indeed, it is possible to test the statistical significance of the difference between the survival curves of different groups through the log-rank test [48]. This test is based on the computation, for each group, of the expected number of companies that cease to operate at each point in time, since the previous one, under the null hypothesis of no difference between groups. For each $i$-th group, the sum of these values across all points in time provides the total expected number of companies' exits, say $E_{i}$. The log-rank test summarizes the discrepancies between the observed number of companies' exits in each group, say $O_{i}$, and $E_{i}$ by means of the following test statistic,

$$
\chi^{2}=\sum_{i=1}^{g} \frac{\left(O_{i}-E_{i}\right)^{2}}{E_{i}} .
$$

Under the null hypothesis of no difference between the survival curves of the groups, the $\chi^{2}$ test statistic follows a Chi-square distribution with $(g-1)$ degrees of freedom, where $g$ is the number of groups.

\subsection{Survival Regression Modelling: The Cox Proportional-Hazards Model}

Regression methods for survival time data attempt to model the relationship between one or more regressors and the so-called hazard function $\lambda_{i}(t)$, which in this empirical context denotes the instantaneous exit rate for company $i$ surviving to time $t$. Consequently, $\lambda_{i}(t) \mathrm{d} t$ gives the probability of company $i$ to exit from market at time $t$, given that it survived until time $t$. Unlike other parametric survival regression models, which require specification of a functional form for $\lambda_{i}(t)$, the semi-parametric Cox proportional-hazards model [49] does not require any distributional assumption.

Under this model, the hazard function for company $i$ varies according to time $t$ and $k$ regressors $\left(x_{1}, x_{2}, \ldots, x_{k}\right)$ as follows:

$$
\lambda_{i}(t)=\lambda_{0}(t) \exp \left(\beta_{1} x_{1 i}+\beta_{2} x_{2 i}+\ldots+\beta_{k} x_{k i}\right)
$$

where $\lambda_{0}(t)$ represents the baseline hazard and $\beta_{1}, \beta_{2}, \ldots, \beta_{k}$ are unknown parameters that need to be estimated. In this formulation there is no need to specify the functional form of $\lambda_{0}(t)$ since it is assumed to be common among all companies. Indeed, the ratio between the hazards of any two generic companies $i$ and $l$ is

$$
\frac{\lambda_{i}(t)}{\lambda_{l}(t)}=\frac{\lambda_{0}(t) \exp \left(\beta_{1} x_{1 i}+\ldots+\beta_{k} x_{k i}\right)}{\lambda_{0}(t) \exp \left(\beta_{1} x_{1 l}+\ldots+\beta_{k} x_{k l}\right)}=\exp \left[\beta_{1}\left(x_{1 i}-x_{1 l}\right)+\ldots+\beta_{k}\left(x_{k i}-x_{k l}\right)\right]
$$

and, therefore, it does not depend on neither $t$ nor $\lambda_{0}(\cdot)$.

Although the specified model does not make any assumption about the data generating process, it does, however, require that the hazards be proportional. The holding of the proportional-hazards assumption can be verified with the Grambsch-Therneau Proportional Hazards (PH) test [50]. The estimation of the model parameters and the associated significance tests can be achieved using the partial likelihood technique [51]. 


\section{Results}

The data analyzed in the present paper concern Italian ISUs and cover the period 2009-2018, which corresponds to the period of the Startup Act. In order to avoid spurious results, ISUs in the agricultural sector have been excluded from the analyses because they are subject to a different legislation about business failure. The first five years of time span have been grouped in one category, due to the small number of units in each year. The total number of startup companies at the end of the period was equal to 9453. Table 1 reports the total number and the percentage of the total of innovative startup companies, distributed by Italian macro-area. At the end of the time span, more than half of the startups (55.1\%) are located in northern Italy (23.3\% in North-East and 31.8\% in North-West), while $20.5 \%$ are located in central Italy and only under a quarter $(24.4 \%)$ in southern Italy. Compared to the beginning of the period, the growth in the number of startups has involved both northern and southern areas of the country, with only central Italy having suffered a considerable decrease.

Table 1. Registered ISUs In Italy by Macro-Area: Numbers ( $n$ ) And Percentages on the Total (\%) At the End of Each Year.

\begin{tabular}{ccccccccccccc}
\hline & \multicolumn{4}{c}{ Until to } & \multicolumn{1}{c}{ to } & $\mathbf{1 2 . 3 1 . 2 0 1 3}$ & $\mathbf{1 2 . 3 1 . 2 0 1 4}$ & $\mathbf{1 2 . 3 1 . 2 0 1 5}$ & $\mathbf{1 2 . 3 1 . 2 0 1 6}$ & $\mathbf{1 2 . 3 1 . 2 0 1 7}$ & $\mathbf{1 2 . 3 1 . 2 0 1 8}$ \\
Macro-Area & $\boldsymbol{n}$ & $\mathbf{\%}$ & $\boldsymbol{n}$ & $\boldsymbol{\%}$ & $\boldsymbol{n}$ & $\boldsymbol{\%}$ & $\boldsymbol{n}$ & $\boldsymbol{\%}$ & $\boldsymbol{n}$ & $\boldsymbol{\%}$ & $\boldsymbol{n}$ & $\boldsymbol{\%}$ \\
\hline North-East & 113 & 20.1 & 388 & 20.9 & 786 & 22.1 & 1250 & 22.9 & 1883 & 23.6 & 2207 & 23.3 \\
North-West & 174 & 31.0 & 558 & 30.0 & 1081 & 30.4 & 1707 & 31.2 & 2495 & 31.3 & 3004 & 31.8 \\
Center & 141 & 25.1 & 391 & 21.0 & 772 & 21.7 & 1148 & 21.0 & 1636 & 20.5 & 1940 & 20.5 \\
South & 133 & 23.7 & 522 & 28.1 & 915 & 25.7 & 1358 & 24.9 & 1959 & 24.6 & 2302 & 24.4 \\
Total & 561 & 100 & 1859 & 100 & 3554 & 100 & 5463 & 100 & 7973 & 100 & 9453 & 100 \\
\hline
\end{tabular}

Regarding the economic sector of activity (according to the NACE classification), most of ISUs belong to the service sector, which is the $76.3 \%$ of the total startup companies at the end of the reference period. The manufacturing sector, with its $18.4 \%$ on the total, constitutes a not negligible share, while startups operating in tourism and trade form together little more than $5 \%$ (Table 2).

Table 2. Registered Isus in Italy by Macro-Sector of Activity: Numbers ( $n$ ) and Percentages of the Total (\%) at the End of Each Year.

\begin{tabular}{|c|c|c|c|c|c|c|c|c|c|c|c|c|}
\hline \multirow{2}{*}{ Sector } & \multicolumn{4}{|c|}{ Until to } & \multicolumn{2}{|c|}{ 12.31.2015 } & \multicolumn{2}{|c|}{ 12.31.2016 } & \multicolumn{2}{|c|}{ 12.31.2017 } & \multicolumn{2}{|c|}{ 12.31.2018 } \\
\hline & $n$ & $\%$ & $n$ & $\%$ & $n$ & $\%$ & $n$ & $\%$ & $n$ & $\%$ & $n$ & $\%$ \\
\hline Manufacturing & 95 & 16.9 & 326 & 17.5 & 631 & 17.8 & 1008 & 18.5 & 1474 & 18.5 & 1736 & 18.4 \\
\hline Services & 434 & 77.4 & 1437 & 77.3 & 2721 & 76.6 & 4140 & 75.8 & 6053 & 75.9 & 7208 & 76.3 \\
\hline Tourism & 6 & 1.1 & 13 & 0.7 & 31 & 0.9 & 49 & 0.9 & 81 & 1.0 & 92 & 1.0 \\
\hline Trade & 26 & 4.6 & 83 & 4.5 & 171 & 4.8 & 266 & 4.9 & 365 & 4.6 & 4,17 & 4.4 \\
\hline Total & 561 & 100 & 1859 & 100 & 3554 & 100 & 5463 & 100 & 7973 & 100 & 9453 & 100 \\
\hline
\end{tabular}

The first research question that we aim to address concerns verification of whether green innovative startup companies have a higher or lower survival performance compared to the non-green innovative startups. In order to address this question, we have computed the KM survival curves and implemented the Cox proportional-hazard model. In using the described dataset, we had to deal with several missing values in some variables. Therefore, the number of observations varies among the different analyses.

Panel (a) of Figure 1 shows the KM curves for 9453 ISUs in Italy in the 2009-2018 period. The estimated survival probability after 8 years of activity is nearly $57.5 \%$, indicating that more than half of the considered companies are still in the market at the end of the observational period. 


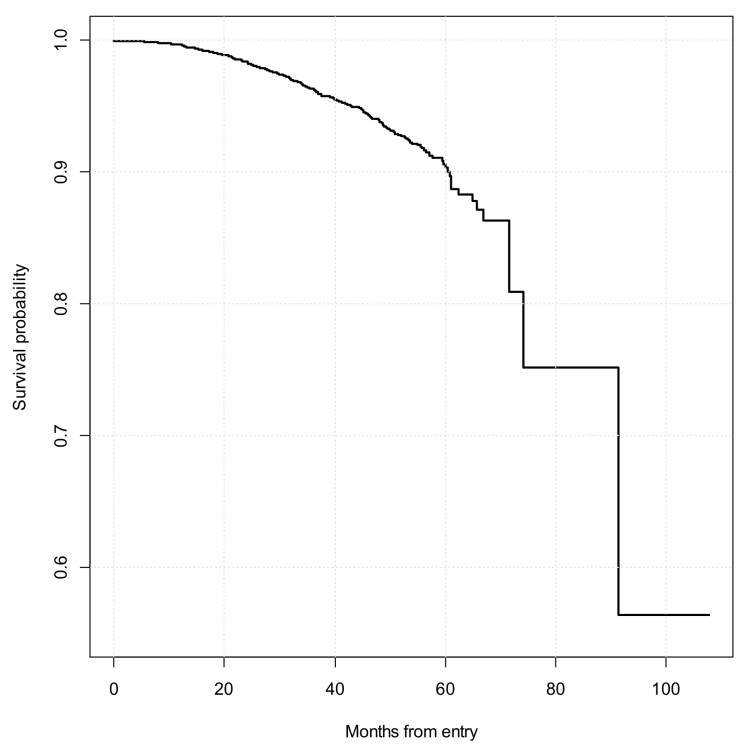

(a)

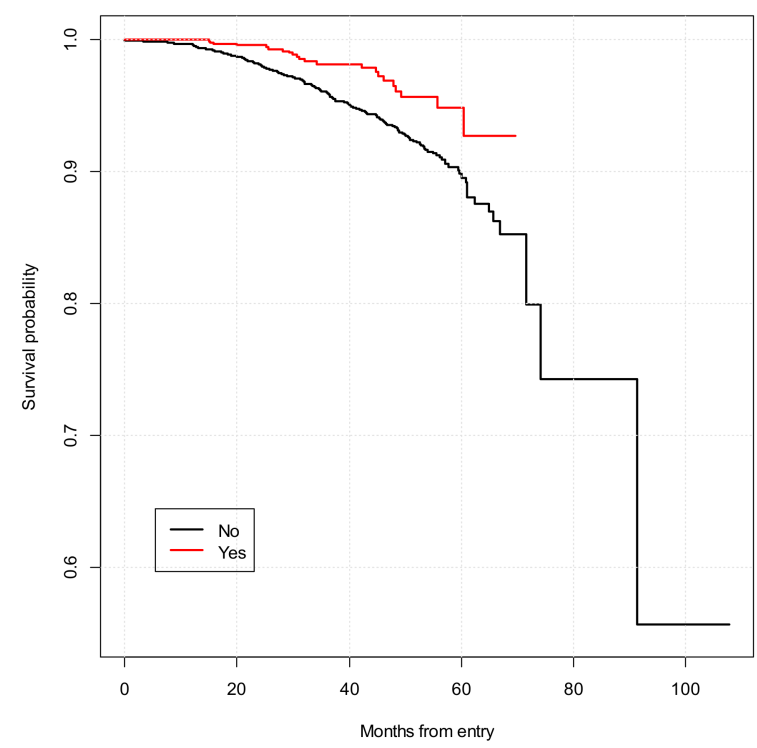

(b)

Figure 1. Kaplan-Meier Estimates of Survival Probability of 9453 Isus in Italy for the Period 2009-2018. on the $X$-axis Is Reported the Time (in Number of Months) From When a Company Enters the Market, Defined as First Registration in the Italian Business Register. on the $Y$-axis Is Reported the Cumulative Survival Probability. Panel (a) Shows the Kaplan-Meier Curve for All Considered Startups, while Panel (b) Shows Kaplan-Meier Curves for Green and Non-Green Isus (Logrank test $\chi^{2}=13.7$, $p$-value $=0.000$ ).

Focusing on the comparison between green and non-green innovative startups, Figure $1 \mathrm{~b}$ shows that the survival performance of the former is very high, so that over $92 \%$ of the companies observed do not experience the exit from the market. The conducted analysis highlights a clear distinction in the performance of green startup companies compared to non-green ones. In particular, the former have a substantially better survival performance with respect to the latter ones. With a $p$-value approximately equal to zero, the Logrank test shows also that the difference between their survival curves is indeed statistically significant. 
This difference, however, could be at least partially due to the particular regulation of the innovative startups instead of structural differences between green and non-green companies. In fact, since the introduction of regulation 221/2012 and especially from the introduction of regulation 221/2015 to promote the green economy, considerable benefits are granted to stimulate the run-up to sustainability. Innovative startup companies that promote the achievement of this aim may benefit of substantial reduction in costs and tax charges, allowing them to not incur liquidity crises, unsustainable leverage and difficulty in finding funding sources, which are only a few examples of decisive causes of the premature exit from the market $[20,22,52,53]$.

This consideration is supported by the results provided by Figure 2, which shows the impact of two economic and financial performance measures on the survival of ISUs, that is the Return On Assets (ROA) indicator and the Debt-to-Equity ratio (D/E). The choice to use these measures to capture the effect of the financial characteristics of companies is twofold. Firstly, other items in the financial statements had a large number of missing values; in fact, it is possible to note that the total number of units is lower than that previously used, and the startups considered were all born before 2017 . Secondly, this information will be used as control variables in the following analyses. For both the $\mathrm{ROA}$ and $\mathrm{D} / \mathrm{E}$ indicators, firms are grouped into quartiles to simply illustrate the differences between companies with higher and lower values (Figure 2).

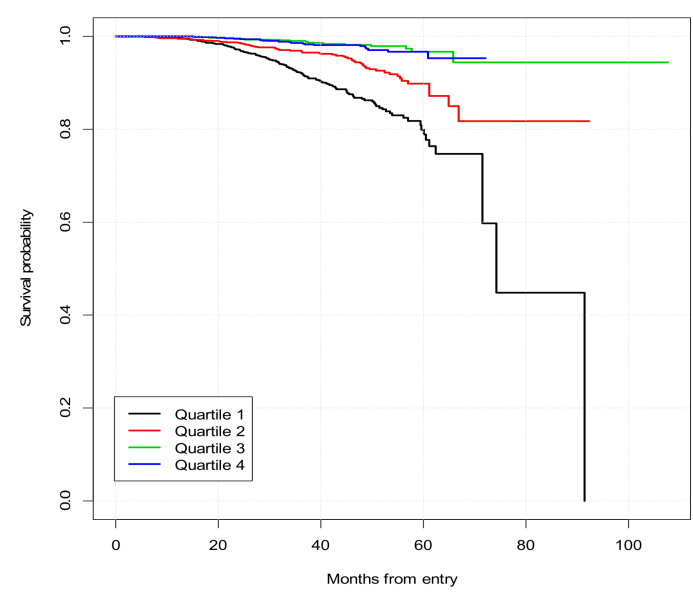

(a)

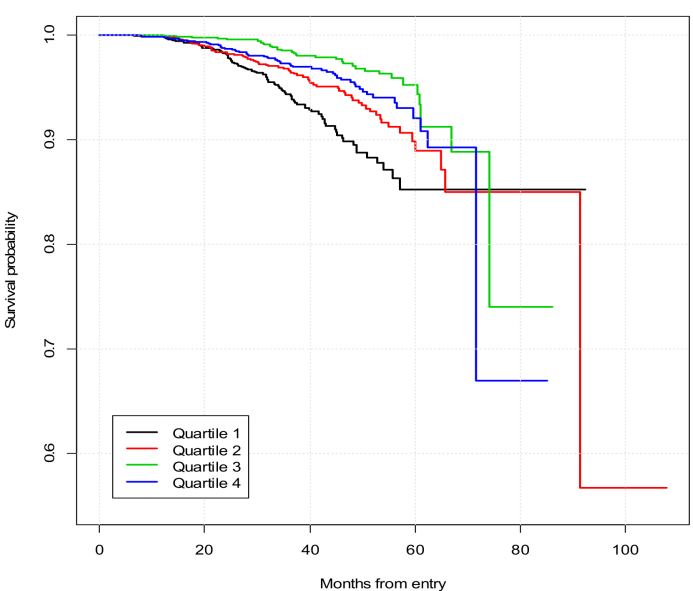

(b)

Figure 2. Panel (a): Kaplan-Meier survival curves of 5327 ISUs in Italy, born before 2017, analyzed by ROA for the period 2009-2018 (Logrank test $\chi^{2}=160, p$-value $\left.=0.000\right)$. Panel $(\mathbf{b})$ : Kaplan-Meier survival curves of 5014 ISUs in Italy, born before 2017, analyzed by debt to equity ratio for the period 2009-2018 (Logrank test $\chi^{2}=41.7, p$-value $\left.=0.000\right)$.

Results of the analysis show that companies with a high ability to remunerate assets, have a better response in terms of survival probability. Companies with a ROA value located in the third and fourth quartiles of the distribution have a survival probability that is never less than $90 \%$ in the considered period. Concerning the $\mathrm{D} / \mathrm{E}$, the findings are in line with the literature and highlight how a lower pressure of debt on capital favors the chances of survival. Low levels of debt can increase survival probability in at least two ways. On one hand, this makes the future cash flows of a company more secure, as they will not be absorbed as a priority by the debt holders but can instead be used for normal business operations or further investments [54]. On the other hand, companies with a low leverage ratio can look at new debt as a valid path to be taken to meet future needs [22].

Therefore, in order to assess the effect of greenness in production on the survival performance of innovative startups while controlling for their financial conditions, as measured by ROA and D/E indicators, we also fitted a Cox proportional-hazard model. We estimated two models with three 
explanatory variables (Model 1 and Model 2) and we introduced the two control variables, namely ROA and D/E, in Model 3. Results of the estimation are reported in Table 3.

Table 3. Results from the Estimation of Cox Proportional-Hazard Models. Coefficients and Standard Errors (in parentheses) are Reported for Each Explanatory Variable Used in the Model.

\begin{tabular}{|c|c|c|c|}
\hline \multirow{2}{*}{ Parameter } & \multirow{2}{*}{$\begin{array}{l}\text { All Companies } \\
\text { Model } 1\end{array}$} & \multicolumn{2}{|c|}{ Companies Born before 2017} \\
\hline & & Model 2 & Model 3 \\
\hline EnergyRelated-YES & $-0.79(0.22)^{* * *}$ & $-0.72(0.23)^{* * *}$ & $-0.63(0.24)^{* * *}$ \\
\hline Industry-Services & $0.35(0.17) * *$ & $0.32(0.18) *$ & $0.30(0.19)$ \\
\hline Industry-Tourism & $1.17(0.41)^{* * *}$ & $1.17(0.44)^{* * *}$ & $0.88(0.53)$ * \\
\hline Industry-Trade & $0.49(0.28) *$ & $0.51(0.29) *$ & $0.43(0.30)$ \\
\hline ROA-quartile 2 & & & $-0.78(0.15)^{* * *}$ \\
\hline ROA_quartile 3 & & & $-1.87(0.24)^{* * *}$ \\
\hline ROA—quartile 4 & & & $-1.71(0.22)^{* * *}$ \\
\hline Debt2Equity—quartile 2 & & & $-0.12(0.17)$ \\
\hline Debt2Equity—quartile 3 & & & $-0.84(0.20)^{* * *}$ \\
\hline Debt2Equity—quartile 4 & & & $-0.40(0.18)^{* *}$ \\
\hline YearOfEntry—2014 & $0.11(0.21)$ & $0.11(0.21)$ & $0.10(0.21)$ \\
\hline YearOfEntry-2015 & $0.73(0.23) * * *$ & $0.73(0.23) * * *$ & $0.61(0.23) * * *$ \\
\hline YearOfEntry-2015 & $0.86(0.26)^{* * *}$ & $0.86(0.26)^{* * *}$ & $0.67(0.28) * *$ \\
\hline YearOfEntry—2015 & $1.49(0.31)^{* * *}$ & & \\
\hline YearOfEntry—2015 & $1.06(0.80)$ & & \\
\hline Num. obs. & 9453 & 5463 & 5010 \\
\hline Missings & 5 & 5 & 458 \\
\hline Num. events & 294 & 260 & 241 \\
\hline AIC & 4695.90 & 4079.72 & 3598.62 \\
\hline Num. events & 294 & 260 & 241 \\
\hline PH test & 0.90 & 0.72 & 0.72 \\
\hline
\end{tabular}

Model 1 has been estimated on the entire dataset covering the entire period, while Model 2 and Model 3 have been fitted only on startup companies born before 2017, due to the high number of missing elements in the control variables for the last two years.

Being a green ISU positively and significantly influences the survival chances in all the three models. In particular, the hazard ratios, computed as an exponential function of the coefficient, report that green startups have a failure rate equal to $53.2 \%$ if compared to the others (Model 3) while controlling for ROA, D/E and sector of activity. This means that a green company is more than twice as likely to survive than a non-green company.

Moreover, focusing on the sector of activity, both Model 1 and Model 2 report significance of coefficients and hazard ratios, indicating a higher probability of leaving the market for services, tourism and trade sectors, compared to manufacturing. The result is not surprising, considering that the startups operating in the manufacturing sector are those with the highest survival chances.

Although the results are in line with the KM curves, it is necessary to highlight a loss of statistical significance of the coefficients associated with the control variables. As ROA increases, the instantaneous exit potential decreases. The same consideration may be done for $\mathrm{D} / \mathrm{E}$, which seems to have a strongly negative impact on the survival performance of innovative startups.

Model 3 has the smallest value for the AIC criterion and hence has to be preferred because it has a relatively better fit. Finally, the Grambsch-Therneau test (P.H. test) has been also performed to assess the hypothesis of proportional hazards assumption. For all three models, the PH test statistics are not significant, with an associated $p$-value greater than 0.10 , and hence the proportional hazards assumption is respected. 


\section{Discussion}

Our analysis has provided strong evidence that innovative startups that follow an environmentally sustainable production process have relatively higher chances of surviving in the market. This result is in line with the recent literature on the relationship between innovation, sustainability and business survival. Indeed, using a novel methodology to evaluate the sustainable business value of companies and referring to a case study about the healthcare sector, Ref. [55] show that a firm's sustainable business conduct can positively affect total shareholder returns and hence financial performance. Similarly, Ref. [56] found that the German wineries that apply sustainable business models can obtain a sustained competitive advantage. Ref. [57] analyzed self-reported data collected from a sample of Pakistani top managers and concluded that a successful approach to deal with market volatility, and survive in the long run, consists of using technological innovation and innovation management to improve sustainability. Ref. [58] provide some empirical evidence that developing products with an integrated approach based on open innovation and peer production makes it possible to enhance both sustainability, in terms of energy consumption, and cost reduction. Finally, Ref. [59] demonstrate, through a systematic literature review, that innovation in knowledge management has a joint impact on economic and environmental sustainability.

It is therefore undeniable that policies (such as the Italian Startup Act) that aim at fostering green innovation, and hence environmental sustainability, can also, at least partially, favor business survival and growth. However, while the results of this paper make it possible to assess the order of magnitude of the effect of greenness on the survival performance of innovative startups, they do not provide indications about the mechanisms that drive this effect. For example, the positive association between greenness and survival may be explained by a common factor, such as the propensity to innovate: firms that implement green production processes are the most innovative ones; in turn, the most innovative firms have the highest ability to survive $[58,60]$. A further common factor could be the organizational culture: an efficient organization is a critical asset to remain competitive in the market, but, at the same time, is also important to achieve a sustainable environmental performance [61]. Another possible explanation lies in the environmental awareness of consumers: firms that are recognizably eco-friendly can address the growing market segment of green consumers, who tend to be more loyal and more willing to pay higher prices for green products and services [62], which obviously helps with profit margins.

Identifying and disentangling the causal links between greenness in production and business survival can greatly help policy makers in formulating effective measures to achieve both economic and environmental sustainability. Therefore, interesting yet challenging directions for future studies on this issue should focus on empirical analysis to explain how and why the two outcomes are positively associated. Such an analysis would require the collection of further data about the innovation activities of firms, the characteristics of management and the customer base and may be performed through structural equation modeling approaches that make it possible to properly identify how business survival is mediated by the implementation of environmentally sustainable processes.

\section{Conclusions}

In the last twenty years, Western economies have experienced a deep cycle of stagnation. Italy is one of the countries that suffered the most. Startups may represent a possible key to open the gates of recovery, in particular the most innovative ones and those that dedicate the right attention to environmental sustainability. However, because of the typical barriers to market entry, newborn companies may experience premature failures. Hence, the implementation of strong forms of protection to support startups seems to be an unavoidable necessity. The present paper aimed at investigating whether Italian regulations to boost the birth of startups have been successful and whether these newborn companies show survival rates that are different from those of other businesses. Special attention has been dedicated to green startups, in order to understand their differences with respect to the non-green ones. Our empirical findings show that Italian startups turning their 
production to greenness tend to survive longer than their counterparts. This seems to suggest that implementing an environmentally sustainable production process can represent an important asset for newborn companies. The study is, however, limited in scope as it only shows that green startups tend to have significantly higher chances to survive in the market. This is certainly an important and useful empirical finding; nevertheless, in order to draw meaningful policy implications, it is necessary to assess the causal mechanism that makes green startups more resistant. Further research is then needed in this direction.

Author Contributions: The authors have equally contributed to this work. All authors have read and agreed to the published version of the manuscript.

Funding: This research received no external funding.

Conflicts of Interest: Authors declare no conflict of interest.

\section{References}

1. Forbes. The Unfashionable Business of Investing in Startups in the Electronic Data Processing Field. Forbes, 15 August 1976; p. 6.

2. Kirchhoff, B.A.; Newbert, S.L.; Hasan, I.; Armington, C. The Influence of University R \& D Expenditures on New Business Formations and Employment Growth. Entrep. Theory Pract. 2007, 31, 543-559. [CrossRef]

3. Baptista, R.; Esària, V.; Madruga, P. Entrepreneurship, regional development and job creation: The case of Portugal. Small Bus. Econ. 2008, 30, 49-58. [CrossRef]

4. Bygrave, W.; Hay, M.; Ng, E.; Reynolds, P. Executive forum: A study of informal investing in 29 nations composing the Global Entrepreneurship Monitor. Ventur. Cap. 2003, 5, 101-116. [CrossRef]

5. Colombelli, A.; Krafft, J.; Vivarelli, M. To be born is not enough: The key role of innovative start-ups. Small Bus. Econ. 2016, 47, 277-291. [CrossRef]

6. Audretsch, D.B. Innovation and Industry Evolution; MIT Press: Cambridge, MA, USA, 1995.

7. Reynolds, P.D. New and Small Companies in Expanding Markets. Small Bus. Econ. 1997, 9, 79-84. [CrossRef]

8. Hanchi, S.E.; Kerzazi, L. Startup innovation capability from a dynamic capability-based view: A literature review and conceptual framework. J. Small Bus. Strategy 2020, 30, 72-92.

9. Roberts, E.B.; Murray, F.E.; Kim, J.D. Entrepreneurship and Innovation at MIT: Continuing Global Growth and Impact-An Updated Report. Found. Trends Entrep. 2019, 15, 1-55. [CrossRef]

10. Bandera, C.; Thomas, E. The Role of Innovation Ecosystems and Social Capital in Startup Survival. IEEE Trans. Eng. Manag. 2018, 66, 542-551. [CrossRef]

11. Vivarelli, M.; Audretsch, D. The Link between the Entry Decision and Post-entry Performance: Evidence from Italy. Ind. Corp. Chang. 1998, 7, 485-500. [CrossRef]

12. Acs, Z.J.; Audretsch, D.B. Innovation, Market Structure, and Company Size. Rev. Econ. Stat. 1987, 69, 567-574. [CrossRef]

13. Shearman, C.; Burrell, G. New Technology-based Companies and the Emergence of New Industries. New Technol. Work Employ. 1998, 3, 87-99. [CrossRef]

14. Matricano, D. Economic and social development generated by innovative startups: Does heterogeneity persist across Italian macro-regions? Econ. Innov. New Technol. 2020, 1-18. [CrossRef]

15. Birch, D.L. The Job Generation Process; MIT Program on Neighborhood and Regional Change: Cambridge, UK, 1979.

16. Birch, D.L. Job Creation in America: How Our Smallest Companies put the Most People to Work; Free Press: New York, NY, USA, 1987.

17. Phillips, B.D.; Kirchhoff, B.A. Formation, growth and survival; Small firm dynamics in the U.S. Economy. Small Bus. Econ. 1989, 1, 65-74. [CrossRef]

18. Rickne, A.; Jacobsson, S. New Technology-Based Firms in Sweden-A Study of Their Direct Impact on Industrial Renewal. Econ. Innov. New Technol. 1999, 8, 197-223. [CrossRef]

19. Barboza, G.; Capocchi, A. Innovative startups in Italy. Managerial challenges of knowledge spillovers effects on employment generation. J. Knowl. Manag. 2020. [CrossRef]

20. Stinchcombe, A.L. Social structure and organizations. In Cognition and Strategy; Elsevier BV: Amsterdam, The Netherlands, 2004; pp. 229-259. 
21. Gimenez-Fernandez, E.M.; Sandulli, F.D.; Bogers, M. Unpacking liabilities of newness and smallness in innovative start-ups: Investigating the differences in innovation performance between new and older small firms. Res. Policy 2020, 49, 104049. [CrossRef]

22. Wiklund, J.; Baker, T.; Shepherd, D. The age-effect of financial indicators as buffers against the liability of newness. J. Bus. Ventur. 2010, 25, 423-437. [CrossRef]

23. LaZear, E.P. Balanced Skills and Entrepreneurship. Am. Econ. Rev. 2004, 94, 208-211. [CrossRef]

24. Dahl, M.S.; Reichstein, T. Are You Experienced? Prior Experience and the Survival of New Organizations. Ind. Innov. 2007, 14, 497-511. [CrossRef]

25. Mayr, S.; Mitter, C.; Kücher, A.; Duller, C. Entrepreneur characteristics and differences in reasons for business failure: Evidence from bankrupt Austrian SMEs. J. Small Bus. Entrep. 2020, 1-20. [CrossRef]

26. Eisenhardt, K.M.; Schoonhoven, C.B. Organizational Growth: Linking Founding Team, Strategy, Environment, and Growth Among U.S. Semiconductor Ventures, 1978-1988. Adm. Sci. Q. 1990, 35, 504. [CrossRef]

27. Vedula, S.; Kim, P.H. Gimme shelter or fade away: The impact of regional entrepreneurial ecosystem quality on venture survival. Ind. Corp. Chang. 2019, 28, 827-854. [CrossRef]

28. Shapero, A.; Giglierano, J. Exits and entries: A study in yellow pages journalism. In Frontiers of Entrepreneurship Research; Vesper, K.H., Ed.; Babson College: Wellesley, MA, USA, 1982; pp. 113-141.

29. Cánovas-Saiz, L.; March-Chordà, I.; Yagüe-Perales, R.M. New evidence on accelerator performance based on funding and location. Eur. J. Manag. Bus. Econ. 2020, 29, 217-234. [CrossRef]

30. Russo, P.F.; Magri, S.; Rampazzi, C. Innovative Start-Ups in Italy: Their Special Features and the Effects of the 2012 Law. SSRN Electron. J. 2016, 2, 297-329. [CrossRef]

31. Finnegan, S.; Jones, C.; Sharples, S. The embodied CO2e of sustainable energy technologies used in buildings: A review article. Energy Build. 2018, 181, 50-61. [CrossRef]

32. Garbasso, G. Verso Un'economia Verde: La Nuova Sfida Dell'europa; Fazi Editore: Roma, Italy, 2014.

33. Crespi, F.; Ghisetti, C.; Quatraro, F. Environmental and innovation policies for the evolution of green technologies: A survey and a test. Eurasian Bus. Rev. 2015, 5, 343-370. [CrossRef]

34. Iazzolino, G.; De Carolis, M.; Clemeno, P. Energy innovative start-ups and knowledge- based strategies: The italian case. Int. J. Energy Econ. Policy 2019, 9, 88-102. [CrossRef]

35. Söderblom, A.; Samuelsson, M. Sources of capital for innovative start-up companies. An empirical study of the Swedish situation. Entreprenörskapsforum 2014, 9, 15-39.

36. Autio, E.; Parhankangas, A. Employment generation potential of new, technology-based companies during a recessionary period: The case of Finland. Small Bus. Econ. 1998, 11, 113-123. [CrossRef]

37. Ejermo, O.; Xiao, J. Entrepreneurship and survival over the business cycle: How do new technology-based firms differ? Small Bus. Econ. 2014, 43, 411-426. [CrossRef]

38. Storey, D.J.; Tether, B.S. New technology-based companies in the European Union: An introduction. Res. Policy 1998, 26, 933-946. [CrossRef]

39. Mazzanti, M.; Zoboli, R. Environmental efficiency and labour productivity: Trade-off or joint dynamics? A theoretical investigation and empirical evidence from Italy using NAMEA. Ecol. Econ. 2009, 68, 1182-1194. [CrossRef]

40. Costantini, V.; Mazzanti, M.; Montini, A. Environmental performance, innovation and spillovers. Evidence from a regional NAMEA. Ecol. Econ. 2013, 89, 101-114. [CrossRef]

41. Gilli, M.; Mancinelli, S.; Mazzanti, M. Innovation complementarity and environmental productivity effects: Reality or delusion? Evidence from the EU. Ecol. Econ. 2014, 103, 56-67. [CrossRef]

42. Arbia, G.; Espa, G.; Giuliani, D.; Micciolo, R. A spatial analysis of health and pharmaceutical company survival. J. Appl. Stat. 2017, 44, 1560-1575. [CrossRef]

43. Giraudo, E.; Giudici, G.; Grilli, L. Entrepreneurship policy and the financing of young innovative companies: Evidence from the Italian Startup Act. Res. Policy 2019, 48, 103801. [CrossRef]

44. Schick, H.; Marxen, S.; Freimann, J. Sustainability Issues for Start-up Entrepreneurs. Greener Manag. Int. 2002, 2002, 56-70. [CrossRef]

45. Ministry of Economic Development. The Italian Startup Act. Italy's National Strategy to Support Innovative Startups and Innovative SMEs; MISE: Rome, Italy, 2019.

46. Unioncamere and Fondazione Symbola. GreenItaly Report 2019. Available online: https://www.symbola. net/ricerca/greenitaly-2019/ (accessed on 8 October 2020). 
47. Kaplan, E.L.; Meier, P. Nonparamentric estimation from incomplete observations. J. Am. Stat. Assoc. 1958, 53, 457-481. [CrossRef]

48. Peto, R.; Pike, M.C.; Armitage, P.; Breslow, N.E.; Cox, D.R.; Howard, S.V.; Mantel, N.; McPherson, K.; Peto, J.; Smith, P.G. Design and analysis of randomized clinical trials requiring prolonged observation of each patient. II. Analysis and examples. Br. J. Cancer 1977, 35, 1-39. [CrossRef]

49. Cox, D.R. Regression Models and Life-Tables. J. R. Stat. Soc. Ser. B 1972, 34, 187-202. [CrossRef]

50. Grambsch, P.M.; Therneau, T.M. Proportional hazards tests and diagnostics based on weighted residuals. Biometrika 1994, 81, 515-526. [CrossRef]

51. Cox, D.R. Partial likelihood. Biometrika 1975, 62, 269-276. [CrossRef]

52. Swaminathan, A.; Baum, J.A.; Singh, J.V. Organizational Ecology: Neither Straightjacket Nor Big Tent. Adm. Sci. Q. 1996, 41, 543. [CrossRef]

53. Hannan, M.T.; Freeman, J. Structural Inertia and Organizational Change. Am. Sociol. Rev. 1984, 49, 149-164. [CrossRef]

54. Panno, A. An empirical investigation on the determinants of capital structure: The UK and Italian experience. Appl. Financ. Econ. 2003, 13, 97-112. [CrossRef]

55. Buchholz, H.; Eberle, T.; Klevesath, M.; Jürgens, A.; Beal, D.; Baic, A.; Radeke, J. Forward Thinking for Sustainable Business Value: A New Method for Impact Valuation. Sustainability 2020, 12, 8420. [CrossRef]

56. Dressler, M.; Paunović, I. Towards a conceptual framework for sustainable business models in the food and beverage industry. Br. Food J. 2019, 122, 1421-1435. [CrossRef]

57. Zhang, Y.; Khan, U.; Lee, S.; Salik, M. The Influence of Management Innovation and Technological Innovation on Organization Performance. A Mediating Role of Sustainability. Sustainability 2019, 11, 495. [CrossRef]

58. Cappa, F.; Del Sette, F.; Hayes, D.; Rosso, F. How to Deliver Open Sustainable Innovation: An Integrated Approach for a Sustainable Marketable Product. Sustainability 2016, 8, 1341. [CrossRef]

59. Centobelli, P.; Cerchione, R.; Esposito, E. Knowledge Management in Startups: Systematic Literature Review and Future Research Agenda. Sustainability 2017, 9, 361. [CrossRef]

60. Costa, J.; Matias, J.C.D.O. Open Innovation 4.0 as an Enhancer of Sustainable Innovation Ecosystems. Sustainability 2020, 12, 8112. [CrossRef]

61. Adebayo, O.P.; Worlu, R.; Moses, C.L.; Ogunnaike, O.O. An Integrated Organisational Culture for Sustainable Environmental Performance in the Nigerian Context. Sustainability 2020, 12, 8323. [CrossRef]

62. Wei, S.; Ang, T.; Jancenelle, V.E. Willingness to pay more for green products: The interplay of consumer characteristics and customer participation. J. Retail. Consum. Serv. 2018, 45, 230-238. [CrossRef]

Publisher's Note: MDPI stays neutral with regard to jurisdictional claims in published maps and institutional affiliations.

(C) 2020 by the authors. Licensee MDPI, Basel, Switzerland. This article is an open access article distributed under the terms and conditions of the Creative Commons Attribution (CC BY) license (http://creativecommons.org/licenses/by/4.0/). 